\title{
Variant estrogen receptor- $\alpha$ messenger RNA expression in hormone-independent human breast cancer cells
}

\section{A S Coutts, E Leygue and L C Murphy}

Department of Biochemistry and Molecular Biology, University of Manitoba, 770 Bannatyne Avenue, Winnipeg, Manitoba, Canada R3E 0W3

(Requests for offprints should be addressed to A S Coutts; Email: 1cmurph@cc.umanitoba.ca)

\begin{abstract}
T5-PRF cells are insensitive to the growthstimulatory effects of estrogen while still retaining expression of estrogen receptor- $\alpha(\mathrm{ER}-\alpha)$. In the apparent absence of ligand, T5-PRF cells have a $3 \cdot 6 \pm 0.5$ (s.E.M.)-fold increased basal ER- $\alpha$ activity and elevated basal progesterone receptor levels compared with the parent, estrogen-sensitive, T5 cells. Long-range ER- $\alpha$ reverse transcription-PCR was performed to characterize variant ER- $\alpha$ mRNA expression in the two cell lines. An increased relative expression of an exon 3/4-deleted ER- $\alpha$ mRNA variant was found in T5-PRF. Recombinant expression of this ER- $\alpha$ variant resulted in
\end{abstract}

significantly increased estrogen responsiveness, as well as a trend to increased basal ligandindependent activity when expressed with wild-type ER- $\alpha$ in ER-negative cell lines, as well as significantly increasing both ligand-independent and estrogen-induced ER- $\alpha$ transcriptional activity when expressed in parental T5 cells. These results suggest a role for altered variant ER- $\alpha$ in ligand-independent activation of ER- $\alpha$ which may contribute to hormone independence in breast tumors.

Fournal of Molecular Endocrinology (1999) 23, 325-336

\section{INTRODUCTION}

Breast cancer is a hormonally responsive cancer and hormones, including estrogen, are required for breast cancer growth (Dickson 1991). Estrogens promote the growth of human breast cancer, and as such, most endocrine therapies are aimed at blocking the growth-promoting effects of estrogen (e.g. antiestrogen such as tamoxifen). Breast cancers are classified according to their requirement for proliferation as being either hormone dependent or hormone independent, based ultimately on the response to endocrine therapy of metastatic disease (Nandi et al. 1995). The level of estrogen receptor- $\alpha$ $(\mathrm{ER}-\alpha)$ in human breast cancer is used as a marker not only of potential therapeutic response to endocrine therapy, but as a marker of prognosis and survival (Merkel \& Osborne 1989).

The evolution of breast cancer into an estrogenindependent growth phenotype is thought to be an important step in the progression of breast cancer to hormone independence and endocrine therapy resistance (Clarke et al. 1990, Leonessa et al. 1992). Understanding the factors that contribute to the development of a hormone-independent phenotype is of major importance in terms of breast cancer therapeutics. Resistance to endocrine therapies may be due to a number of factors. In some cases, hormone independence and resistance can occur due to loss of ER expression, but most tumors that have developed resistance to endocrine therapy remain receptor positive (Horwitz 1993).

Several breast cancer cell lines in culture also require estrogen for growth, and long-term culture in estrogen-depleted conditions can result in cells becoming apparently independent of the requirement for estrogen for growth. Indeed, the development of estrogen-independent growth in human breast cancer is thought to be one of the initial steps in the progression to hormone independence and resistance to endocrine therapies (Leonessa et al. 1992). However, the mechanisms responsible for the development of estrogen independence in the presence of continued expression of ER- $\alpha$ are poorly understood. In order to address this we have developed a breast cancer cell model of apparent estrogen independence (Coutts et al. 1996). T5 human breast cancer cells are ER- $\alpha$ positive and 
estrogen treatment in culture results in increased proliferation of these cells. An estrogennonresponsive cell line, T5-PRF, was developed from T5 cells by chronically depleting the cells of estrogen in long-term culture. These cells are insensitive to the growth-stimulatory effects of estrogen seen in the parent cell line while still retaining expression of the ER- $\alpha$ (Coutts et al. 1996). However, these cells remain sensitive to the growth inhibitory effects of 4-hydroxy-tamoxifen (OT) and ICI 164,384 (ICI), although they have reduced sensitivity to ICI compared with the parent T5 cells (Coutts et al. 1996).

We have investigated the ligand-dependent and -independent activity of the endogenous ER- $\alpha$ as well as the pattern and potential function of ER- $\alpha$ variant expression in T5 and T5-PRF human breast cancer cells.

\section{MATERIALS AND METHODS}

\section{Materials}

$\left({ }^{32} \mathrm{P}\right) \mathrm{dCTP}$ and $\left({ }^{35} \mathrm{~S}\right) \mathrm{ATP}$ were purchased from ICN (St-Laurent, Quebec, Canada). Dulbecco's Minimal Essential Medium (DMEM) powder and fetal bovine serum were purchased from $\mathrm{GIBCO} /$ BRL (Burlington, Ontario, Canada). Horse serum and epidermal growth factor (EGF) were purchased from UBI (Lake Placid, New York, NY, USA). All other cell culture ingredients were purchased from Flow Laboratories (Mississauga, Ontario, Canada). Cholera toxin, OT, estradiol-17 $\beta$ (E2) and dexamethasone were obtained from Sigma Chemical Co. (St Louis, MO, USA). $\left[{ }^{14} \mathrm{C}\right]$ Chloramphenicol, $\left[{ }^{3} \mathrm{H}\right] \mathrm{R} 5020 \quad(88.7 \mathrm{Ci} / \mathrm{mmol}),\left[{ }^{35} \mathrm{~S}\right] \mathrm{methionine}$ and R5020 were obtained from NEN (Lachire, Quebec, Canada). ICI was a gift from ICI (Macclesfield, Cheshire, UK).

\section{Cells and cell culture}

T5 cells, previously called T-47D5, were originally thought to be a T-47D subline; however, DNA fingerprinting analysis showed that they were an MCF-7 subline (Watts et al. 1992). T5 and MDA-MB-231 human breast cancer cells were routinely cultured in DMEM containing 5\% $\mathrm{v} / \mathrm{v}$ fetal calf serum, $1 \% \mathrm{w} / \mathrm{v}$ glucose, glutamine and penicillin-streptomycin. T5-PRF cells were routinely cultured in phenol red-free DMEM supplemented with $5 \% \mathrm{v} / \mathrm{v}$ twice charcoal-dextranstripped fetal calf serum and $1 \% \mathrm{w} / \mathrm{v}$ glucose, glutamine, and penicillin-streptomycin (PRF/ DMEM). MCF10A1 human breast epithelial cells (Karmanos Cancer Institute, Detroit, MI, USA) were grown routinely in DMEM containing $5 \% \mathrm{v} / \mathrm{v}$ horse serum, $1 \% \mathrm{w} / \mathrm{v}$ glucose, glutamine and penicillin-streptomycin, $0 \cdot 1 \mu \mathrm{g} / \mathrm{ml}$ cholera toxin, $20 \mathrm{ng} / \mathrm{ml}$ human EGF (hEGF), 10.4 $\mu \mathrm{g} / \mathrm{ml}$ bovine insulin and $1 \mu \mathrm{M}$ hydrocortisone (DMEM-special). Transient transfections and steroid receptor assays were performed in PRF/DMEM. Transient transfections using MCF10A1 cells were performed in phenol red-free DMEM containing $5 \% \quad \mathrm{v} / \mathrm{v}$ charcoal-stripped horse serum, $1 \% \mathrm{w} / \mathrm{v}$ glucose, glutamine and penicillin-streptomycin (PRF/ DMEM-hs) and cells were passaged once prior to transfection in phenol red-free DMEM containing $5 \% \mathrm{v} / \mathrm{v}$ charcoal-stripped horse serum, $1 \% \mathrm{w} / \mathrm{v}$ glucose, glutamine, penicillin-streptomycin, $0 \cdot 1 \mu \mathrm{g} / \mathrm{ml}$ cholera toxin, $20 \mathrm{ng} / \mathrm{ml} \mathrm{hEGF,} 10 \cdot 4 \mu \mathrm{g} / \mathrm{ml}$ bovine insulin and $1 \mu \mathrm{M}$ hydrocortisone (PRF/DMEMspecial).

\section{Progesterone receptor (PR) assays}

PR assays were performed using whole-cell ligandbinding assays as previously described (Murphy \& Dotzlaw $1989 a)$. $\left[{ }^{3} \mathrm{H}\right] \mathrm{R} 5020$ and $\left[{ }^{3} \mathrm{H}\right] 5020$ plus 100-fold molar excess unlabeled R5020 were used to determine PR total and nonspecific binding respectively. All assays were performed in the presence of $100 \mathrm{nM}$ dexamethasone to prevent binding of R5020 to the glucocorticoid receptor.

\section{Transient transfections and chloramphenicol acetyltransferase (CAT) assays}

T5, T5-PRF and MDA-MB-231 cells were passaged once in PRF/DMEM and set up in $100 \mathrm{~mm}$ diameter dishes at $0.5 \times 10^{6}$ cells per dish in PRF/DMEM the day before transfection. MCF10A1 cells were passaged once in PRF/ DMEM-special and set up in $100 \mathrm{~mm}$ diameter dishes at $2 \times 10^{6}$ cells per dish in PRF/DMEMspecial 2 days before transfection. The following day the medium was changed to PRF/DMEM-hs and cells were transfected the following day, using the calcium phosphate/glycerol shock method (Graham \& Van der Eb 1973) using an equal volume $2 \times$ BBS buffer $(50 \mathrm{mM} \quad \mathrm{N}, \mathrm{N}$-bis(2-hydroxyethyl)-2-aminoethanesulfonic acid, $280 \mathrm{mM}$ $\mathrm{NaCl}, 1.5 \mathrm{mM} \mathrm{Na}_{2} \mathrm{HPO}_{4}, \mathrm{pH} 6.95$ ), followed by a 2 min glycerol shock $(20 \% \mathrm{v} / \mathrm{v})$. Cells were washed twice with PBS and given fresh medium plus or minus $10 \mathrm{nM}$ E2, $10 \mathrm{nM}$ E2 plus $1 \mu \mathrm{M}$ ICI or $1 \mu \mathrm{M}$ ICI alone. After $24 \mathrm{~h}$ of treatment, the cells were harvested, cell extracts prepared and CAT activity measured (Kingston 1989). Transfection efficiency was determined by cotransfection of pCH110 ( $\beta$-galactosidase expression vector; Pharmacia, Baie 
d'Urfé, Québec, Canada) and assay of $\beta$ galactosidase activity (Rosenthal 1987) was used to correct volumes of cell extracts used for CAT assay. Therefore all results are expressed as percent CAT activity or fold CAT activity after correction for transfection efficiency. T5 and T5-PRF cells were transfected with $5 \mu \mathrm{g}$ estrogen response element (ERE)-thymidine kinase (tk)-CAT (Seiler-Tuyns et al. 1986), to determine ER- $\alpha$ transcriptional activity, along with $5 \mu \mathrm{g}$ pCH110. In the experiments where activity of exon 3/4-deleted ER- $\alpha$ $(\mathrm{d} 3 / 4)$ was examined in T5 cells, transfections were performed using $5 \mu \mathrm{g}$ ERE-tk-CAT, $5 \mu \mathrm{g}$ pCH110 plus or minus $\mathrm{d} 3 / 4$ expression vector $(0 \cdot 1-1 \mathrm{pmol})$ or vector DNA alone. MDA-MB-231 and MCF10A1 cells were transfected with $5 \mu \mathrm{g}$ ERE-tkCAT, $5 \mu \mathrm{g}$ pCH110, plus or minus 0.5 pmol HEGO (an expression plasmid containing wild-type ER- $\alpha$ coding region cloned into the eukaryotic expression vector pSG5, a gift from Dr P Chambon, Strasbourg, France (Tora et al. 1989a)) with increasing amounts $(0 \cdot 5-2 \mathrm{pmol})$ of $\mathrm{d} 3 / 4$ expression vector or vector DNA alone.

\section{Long-range ER- $\alpha$ reverse transcriptase (RT)-PCR}

Total RNA was extracted (Trizol reagent, GIBCO/ BRL, Grand Island, New York, NY, USA) and reverse transcribed as described previously (Leygue et al. 1996c). The primer pair used consisted of $1 / 8 \mathrm{U}$ primer $\left(5^{\prime}\right.$-TGCCCTACTACCTGGAGA ACG-3', sense; located in WT-ER- $\alpha$ exon 1 ; nucleotides $615-637)$ and $1 / 8 \mathrm{~L}$ primer $\left(5^{\prime}-\mathrm{GCC}\right.$ TCCCCCGTGATGTAA-3', antisense; located in WT-ER- $\alpha$ exon 8; nucleotides 1995-1978). Nucleotide positions given correspond to published sequences of the human ER- $\alpha$ cDNA (Green et al. 1986). PCR amplifications were performed as previously described (Leygue et al. 1996a). PCR products were separated on $3.5 \%$ polyacrylamide gels containing $7 \mathrm{M}$ urea, gels dried and labeled products visualized by autoradiography. PCR products were subcloned and sequenced as previously described (Leygue et al. 1996c).

\section{Construction of variant ER- $\alpha$ expression vector}

The RT-PCR product corresponding to the $\mathrm{d} 3 / 4$ cDNA was cloned into the TA cloning vector (Invitrogen TA cloning kit, Carlsbad, CA, USA). Stu1 digestion of this plasmid released an exon 3/4-deleted fragment which was used to replace the corresponding region of wild-type ER- $\alpha$ from $\mathrm{p} 0 \mathrm{R} 8$ (Tora et al. 1989a) (contains a glycine to valine point mutation at amino acid 400). Stu I sites are in exon 2 and 7 of wild-type ER- $\alpha$ and the subcloned $\mathrm{d} 3 / 4$ PCR fragment resulted in a correction to the wild-type sequence of glycine at amino acid 400 (in exon 5 in pOR8). The full-length EcoRI ER- $\alpha$ fragment from HEGO was then excised and replaced with the corresponding fragment from pOR8 containing the $\mathrm{d} 3 / 4$ cDNA. The identity of the expression plasmid containing the $d 3 / 4$ was confirmed by restriction enzyme digest and sequence analysis.

\section{In vitro transcription and translation}

In vitro transcription/translation reactions were performed using a coupled transcription/translation system (Tn'T coupled Reticulocyte Lysate System, Promega, Madison, WI, USA). Reactions were performed according to the manufacturer's instructions.

\section{Western blotting and immune detection}

Whole-cell extracts (dissolved in $8 \mathrm{M}$ urea) were analyzed using $10 \%$ SDS-PAGE with a $4 \%$ stacking gel at $200 \mathrm{~V}$ for $45 \mathrm{~min}$ at room temperature according to the Laemmli method (Laemmli 1970). Gels were transferred to nitrocellulose using CAPS transfer buffer (10 mM 3-[cyclohexylamino]-1propanesulfonic acid (CAPS), $\mathrm{pH} 11,20 \%$ methanol) and transferred for $1 \mathrm{~h}$ at $120 \mathrm{~V}$ at $4{ }^{\circ} \mathrm{C}$. Blots were blocked for $1 \mathrm{~h}$ at room temperature in $5 \%$ skimmed milk/Tris-buffered saline containing $0 \cdot 5 \%$ Tween-20. Blots were incubated with either ER- $\alpha$-specific primary antibody, H226 (a generous gift from Dr G Greene, University of Chicago, IL, USA), which recognizes an epitope in exon 1/exon 2 region of the wild-type ER- $\alpha$, or the ER- $\alpha$-specific antibody, AER 308 (Neomarkers, Fremont, CA, USA), which recognizes an epitope in exon 4 of the wild-type ER- $\alpha$, overnight at $4{ }^{\circ} \mathrm{C}$ in $1 \%$ skimmed milk/Tris-buffered saline containing $0.5 \%$ Tween20. Blots were then incubated with the appropriate horseradish peroxidase-conjugated secondary antibody for $1 \mathrm{~h}$ at room temperature in $1 \%$ skimmed milk/Tris-buffered saline containing $0.5 \%$ Tween20. Detection was carried out using an enhanced chemiluminescence detection system according to the manufacturer's instructions (Amersham International, Amersham, Bucks, UK).

\section{Statistical analysis}

Statistical analyses of ER- $\alpha$ transcriptional activity and PR levels were performed using paired Student's $t$-test. Statistical analysis on the effects of 
d3/4 on ERE-tk-CAT activity in MDA-MB-231 and MCF10A1 cells was done by ANOVA (two-tailed). Statistical analysis on the effects of d3/4 on ERE-tk-CAT activity in T5 cells was done by ANOVA (two-tailed) after log transformation of the data. Statistical analyses were performed with the help of M Cheang, University of Manitoba, Biostatistical Consulting Unit.

\section{RESULTS}

\section{Apparent ligand-independent (basal) activity of ER- $\alpha$ is increased in T5-PRF cells}

Previously, we have shown that T5-PRF cells (derived by long-term passage of parental T5 cells in estrogen-depleted medium) are no longer growth responsive to estrogen in culture, but still retain expression of ER- $\alpha$ (Coutts et al. 1996). To investigate further the mechanism(s) responsible for estrogen nonresponsiveness in these cells, ER- $\alpha$ transcriptional activity was examined by transient transfection assays using an estrogen-responsive reporter gene. Figure 1A represents the fold difference in CAT activity between T5 and T5-PRF cells. As expected, estrogen treatment increases CAT activity in T5 and to a lesser extent in T5-PRF cells, while the antiestrogen ICI inhibits the estrogen-induced transcriptional activity of the ER- $\alpha$ in both cell lines. In the absence of added estrogen there is a low basal ER- $\alpha$ activity in parental T5 cells; however, in the estrogennonresponsive T5-PRF cells, the basal ER- $\alpha$ activity was $3 \cdot 6 \pm 0 \cdot 5$-fold (mean \pm s.E.M., $n=7$ ) higher than that seen in T5 cells $(P>0 \cdot 05)$. Consistent with the increased basal CAT activity in T5-PRF cells being mediated by ER- $\alpha$, treating cells under basal conditions with ICI alone almost completely abolished the basal transcriptional activity measured (Fig. 1B).

\section{PR levels are elevated in T5-PRF cells}

PR expression is a marker of ER- $\alpha$ activity (Horwitz $\&$ McGuire 1978), therefore we examined PR levels to determine if the increase in basal ER- $\alpha$ activity in T5-PRF cells was reflected in an endogenous estrogen-responsive gene. Under basal (i.e. no added estrogen) conditions the T5-PRF cells have significantly higher PR levels $(\sim 3$-fold) than the parent T5 cells passaged twice in estrogen-depleted medium (PRF/DMEM as defined in Materials and Methods) before receptor assays $\left(464 \pm 20 \mathrm{fmol} / 10^{6}\right.$ cells vs $148 \pm 40 \mathrm{fmol} / 10^{6}$ cells, mean \pm s.E.M., $n=3$, see Fig. 2). Previously, we had shown that T5-PRF
A

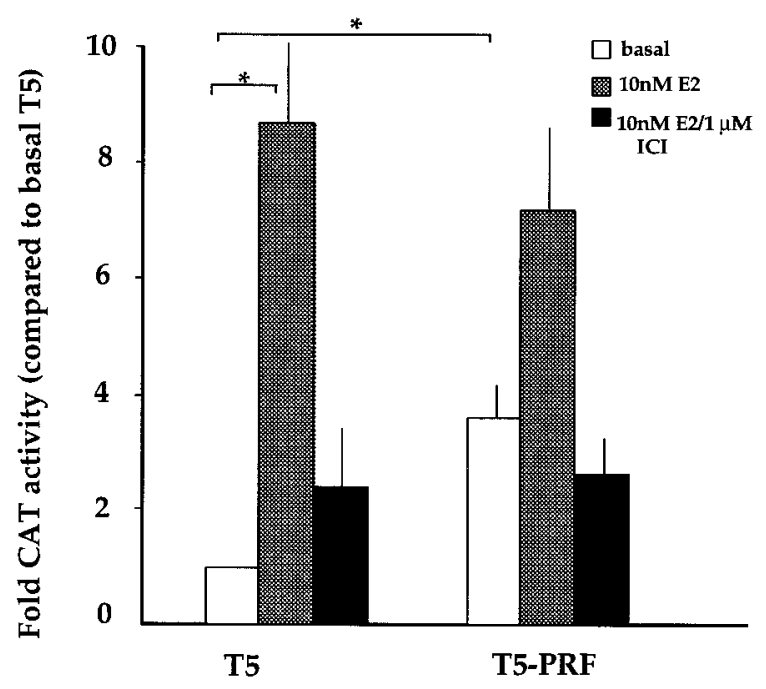

B

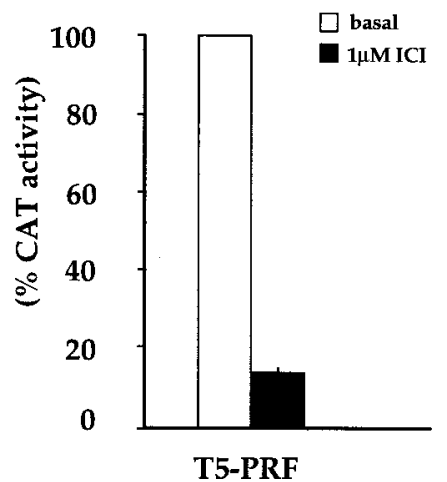

FIGURE 1. ER transcriptional activity. (A) T5 and T5PRF cells were transfected and CAT assays performed as described in Materials and Methods. Results are expressed as fold CAT activity compared with T5 basal (arbitrarily set at $1 \cdot 0$ ). $* P<0 \cdot 05$, Student's $t$-test (compared with T5 basal). Results represent mean \pm s.E.M., $n=7$. (B) T5-PRF cells were transfected and CAT assays performed as described in Materials and Methods. Results represent percent CAT activity as compared with T5-PRF basal set at $100 \%$, mean \pm range, $n=2$.

cells retained expression of ER- $\alpha$ which was approximately $50 \%$ of the levels seen in the parent T5 cells, as determined by a ligand-binding assay (Coutts et al. 1996). Since we observed increased basal activity from both an estrogen-responsive reporter gene and an endogenous estrogenresponsive gene $(\mathrm{PR})$ in T5-PRF cells despite a decreased level of endogenous ligand-binding ER, we reasoned that the intrinsic activity of the wild-type ER in these cells was increased or some 


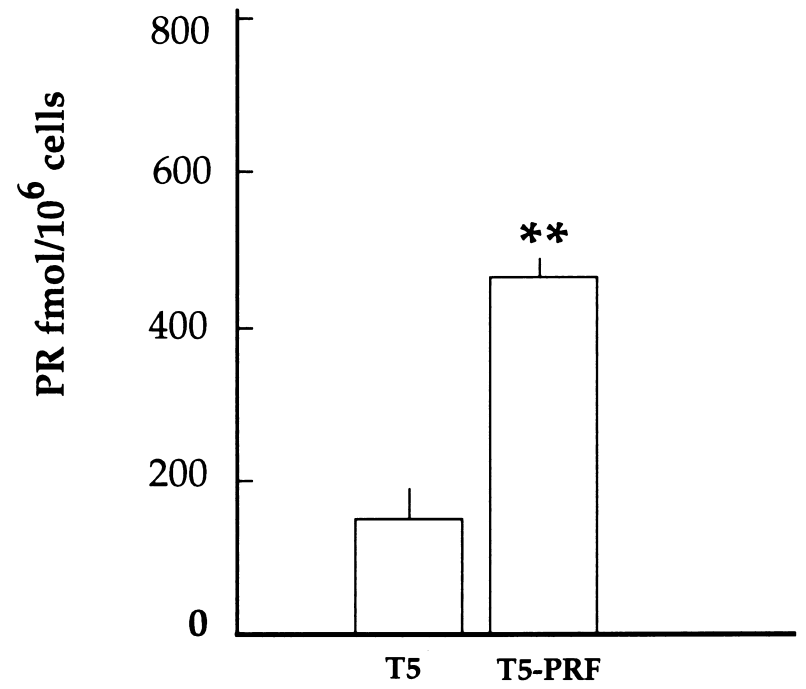

FIGURE 2. PR levels. PR levels were determined by whole-cell binding as described in Materials and Methods. PR levels are expressed as fmol PR $/ 10^{6}$ cells and results represent mean \pm S.E.M., $n=3$. $* * P<0 \cdot 01$, Student's $t$-test.
ER-like activity existed that was not detected by ligand-binding experiments.

\section{Expression of a variant ER- $\alpha$ mRNA deleted in exons 3 and 4 is increased in T5-PRF cells}

Alterations in the structure or presence of variant forms of the ER- $\alpha$ with ligand-independent activity could be one mechanism for our observed results. Long-range ER- $\alpha$ RT-PCR analysis (Leygue et al. 1996a) was performed on RNA isolated from T5 and T5-PRF cells to examine the pattern of deleted variant ER- $\alpha$ mRNA expression. RT-PCR analysis was performed, using a primer pair specific for exons 1 and 8 of the wild-type human ER- $\alpha$ sequence, allowing detection of any variant ER- $\alpha$ mRNA species containing both exons 1 and 8 of wild-type ER- $\alpha$ sequence. Figure 3 shows the PCR products obtained and the presence of a $928 \mathrm{bp}$ band whose relative expression is markedly increased in T5-PRF estrogen-independent cells. To confirm the identity of this variant, the cDNA corresponding to the $928 \mathrm{bp}$ band was subcloned

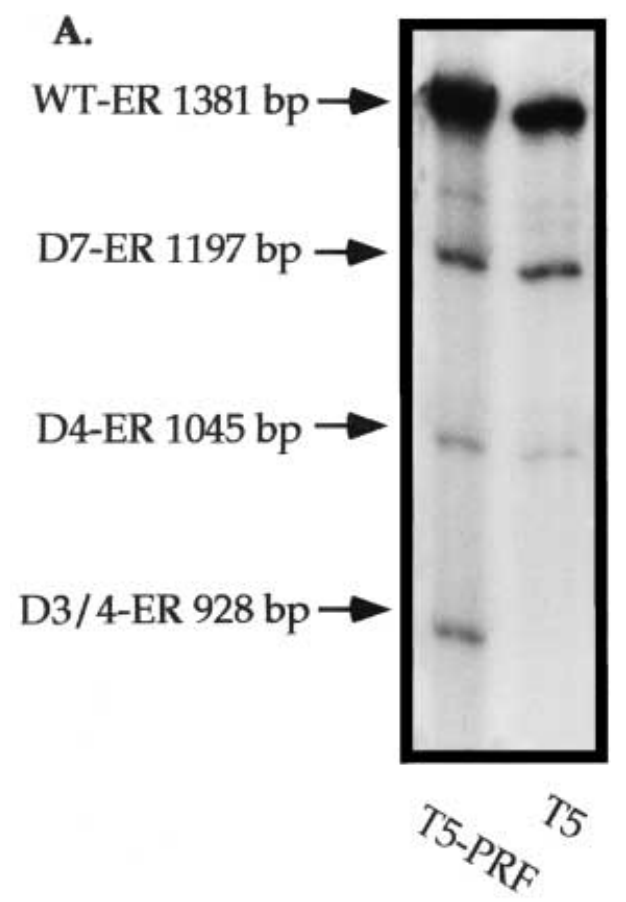

B.

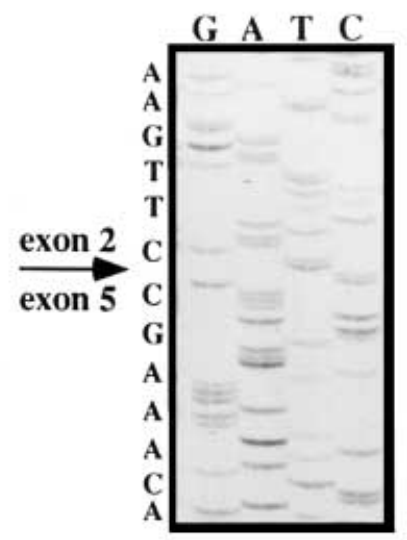

FIGURE 3. Identification of $\mathrm{d} 3 / 4$ mRNA. (A) Long-range ER- $\alpha$ RT-PCR. Total RNA was extracted from T5 and T5-PRF cells, reverse transcribed and PCR amplified using 1/8U and $1 / 8 \mathrm{~L}$ primers. Labeled PCR products were separated on $3 \cdot 5 \%$ acrylamide-urea gels and visualized using autoradiography. WT-ER=wild type ER- $\alpha, \mathrm{D} 7-\mathrm{ER}=$ exon 7 -deleted ER- $\alpha$, D4-ER = exon 4-deleted ER- $\alpha$ and D3/4-ER=exon 3 and 4-deleted ER- $\alpha(\mathrm{d} 3 / 4)$, based on size compared with labeled markers (not shown). (B) Sequence of d3/4 cDNA. The $928 \mathrm{bp}$ PCR product was excised from a gel and subcloned (in triplicate) and three colonies from each independent subcloning were sequenced to confirm the identity of $\mathrm{d} 3 / 4 \mathrm{cDNA}$. 


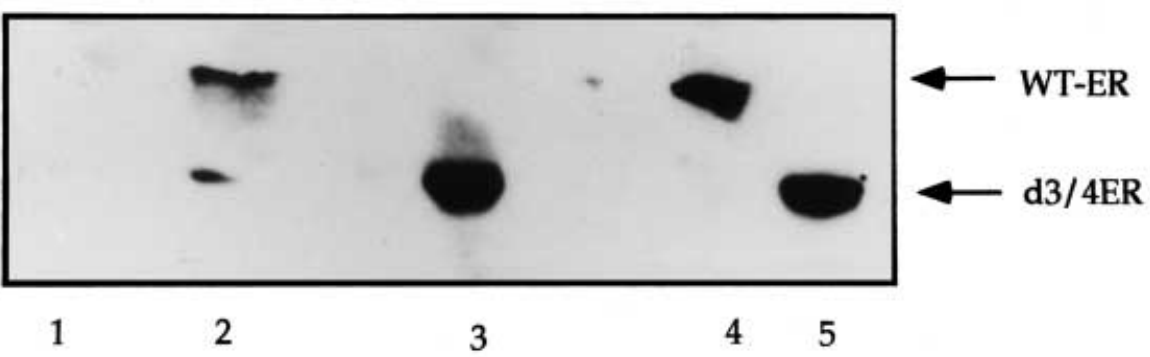

lane 1

2

3

FIGURE 4. In vivo expression of $\mathrm{d} 3 / 4$ protein. MCF10A1 human breast epithelial cells were transfected with the appropriate expression vectors, cells were lysed in $8 \mathrm{M}$ urea and $10 \mu \mathrm{g}$ protein run on a $10 \%$ SDS-acrylamide gel. Gels were transferred to nitrocellulose and Western blotting performed using ER- $\alpha$ Ab H226. Lane 1: control cells transfected with $5 \mu \mathrm{g}$ of vector (pSG5) alone; lane 2: cells transfected with $5 \mu \mathrm{g}$ HEGO (WT-ER- $\alpha$ ) expression vector; lane 3 : cells transfected with $5 \mu \mathrm{g} \mathrm{d} 3 / 4$ expression vector; lane 4 :

in vitro-transcribed/translated WT-ER- $\alpha(1 \mu \mathrm{l})$; lane 5 : in vitro-transcribed/translated $\mathrm{d} 3 / 4$ $(2 \mu \mathrm{l})$.

and sequenced. The nucleotide sequence of the cDNA was found to represent a variant ER- $\alpha$ mRNA containing a deletion of both exons 3 and 4 . This $\mathrm{d} 3 / 4$ is in frame and is predicted to encode a protein of 443 amino acid residues with a predicted molecular mass of $\sim 49 \mathrm{kDa}$. This putative ER- $\alpha$ like protein would be missing the second zinc finger of the ER- $\alpha$ DNA-binding domain (DBD), the hinge region and part of the ligand-binding domain.

\section{The exon 3/4-deleted ER- $\alpha$-like protein increases basal and estrogen-regulated wild-type ER- $\alpha$ transcriptional activity}

To address the potential function of this variant ER- $\alpha$ mRNA eukaryotic expression vectors containing $\mathrm{d} 3 / 4$ cDNA were constructed and shown to express a protein of the appropriate size that was recognized by the ER- $\alpha$ antibody $\mathrm{H} 226$ that recognizes an epitope encoded in exon 1/2 (A/B region) of wild-type ER- $\alpha$ (data not shown). Using an antibody that recognizes an epitope encoded in exon 4 of the wild-type ER- $\alpha$ the band corresponding to the $\mathrm{d} 3 / 4$ protein is not seen, while wild-type ER- $\alpha$ is still detected (data not shown). Ligandbinding analysis of the in vitro-translated $\mathrm{d} 3 / 4$ protein showed little or no ability to specifically bind radiolabeled E2 or OT (data not shown). This protein is missing the second zinc finger of the DBD and as such would not be expected to bind to DNA. We found that under conditions in which in vitro-transcribed/translated wild-type ER- $\alpha$ could bind to an oligonucleotide containing the vitellogenin B1 ERE, d3/4 did not demonstrate any specific DNA binding in gel mobility shift assays (data not shown).
To examine the transcriptional activity of the $\mathrm{d} 3 / 4$ variant, transient transfections using ERnegative cell lines were carried out. Under conditions in which transiently transfected wildtype ER- $\alpha$ was transcriptionally active and able to induce CAT activity in a ligand-dependent fashion, the $\mathrm{d} 3 / 4$ did not demonstrate any transcriptional activity on its own (data not shown). This is unlikely to be due to low levels of expression of this transgene, since after transfection of $5 \mu \mathrm{g} \mathrm{d} 3 / 4$ vector into MCF10A1 cells we were able to detect a protein corresponding in size to the expected $\mathrm{d} 3 / 4$ protein (Fig. 4). To determine if $\mathrm{d} 3 / 4$ and wild-type ER- $\alpha$ could interact to influence transcription, cotransfections of wild-type ER- $\alpha$ and $\mathrm{d} 3 / 4$ into MDA-MB-231 and MCF10A1 ER-negative breast epithelial cell lines were carried out (Fig. 5A and B). HEGO transfected alone showed the expected estrogen-dependent activity (Fig. 5A and B) while $\mathrm{d} 3 / 4$ alone had no transcriptional activity. However, when increasing amounts of $\mathrm{d} 3 / 4$ were cotransfected with a constant amount of HEGO into MDA-MB231 cells, d3/4 significantly increased estrogendependent activity of wild-type ER- $\alpha$ (ANOVA, $P<0 \cdot 0001)$. Furthermore, although it did not reach statistical significance there was a trend of increased $\mathrm{d} 3 / 4$ to increase the basal level of activity of the wild-type ER- $\alpha$. This pattern of activity was also seen when similar experiments were carried out in MCF10A1 cells. A significant increase in the estrogen-dependent activity was seen (ANOVA, $P<0 \cdot 05$ ), with a trend towards increased basal activity.

We next examined the effects of introducing the $\mathrm{d} 3 / 4$ into the parental $\mathrm{T} 5$ cells. Transient transfection of d $3 / 4$ into T 5 cells was carried out and ER- $\alpha$ transcriptional activity measured. Figure 6 shows 
the results, and demonstrates that increasing amounts of $\mathrm{d} 3 / 4$ transiently transfected into $\mathrm{T} 5$ cells were associated with a significant increase in CAT activity in both the presence and absence of added estrogen (ANOVA, $P<0 \cdot 05$ and $P<0 \cdot 0001$ respectively) despite the fact that this variant ER- $\alpha$

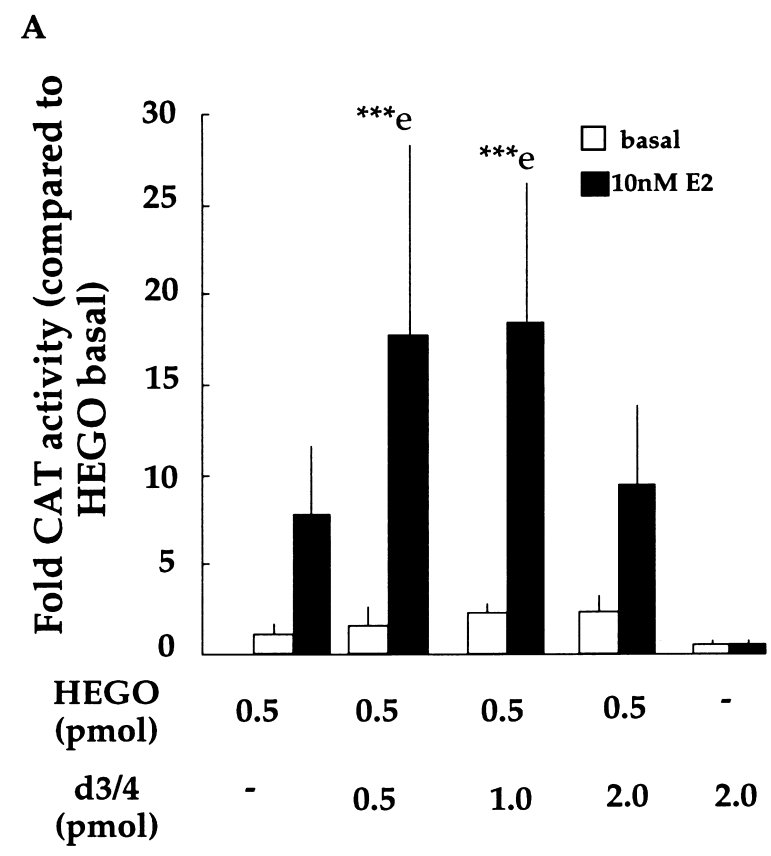

B

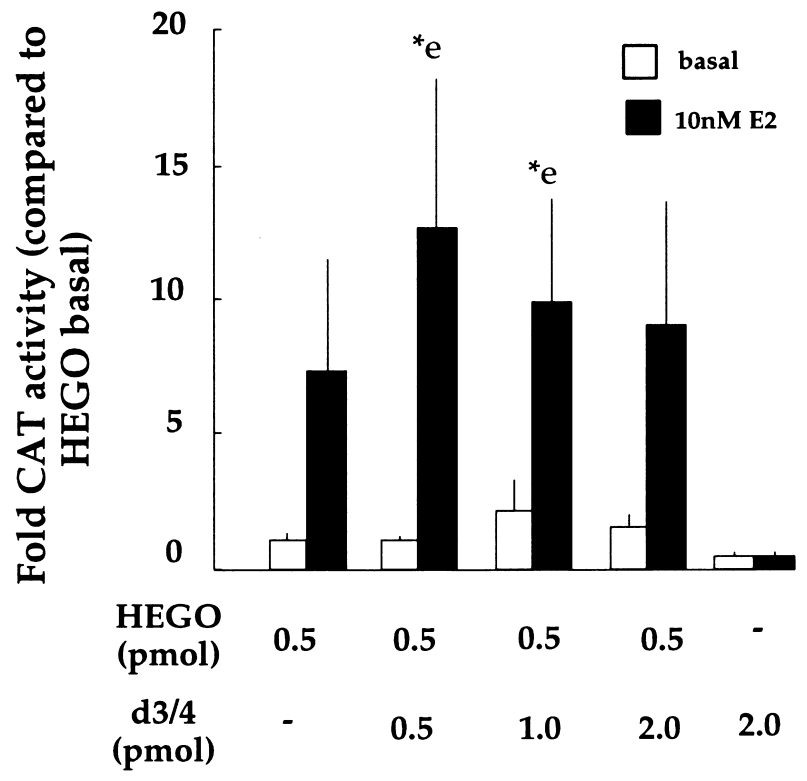

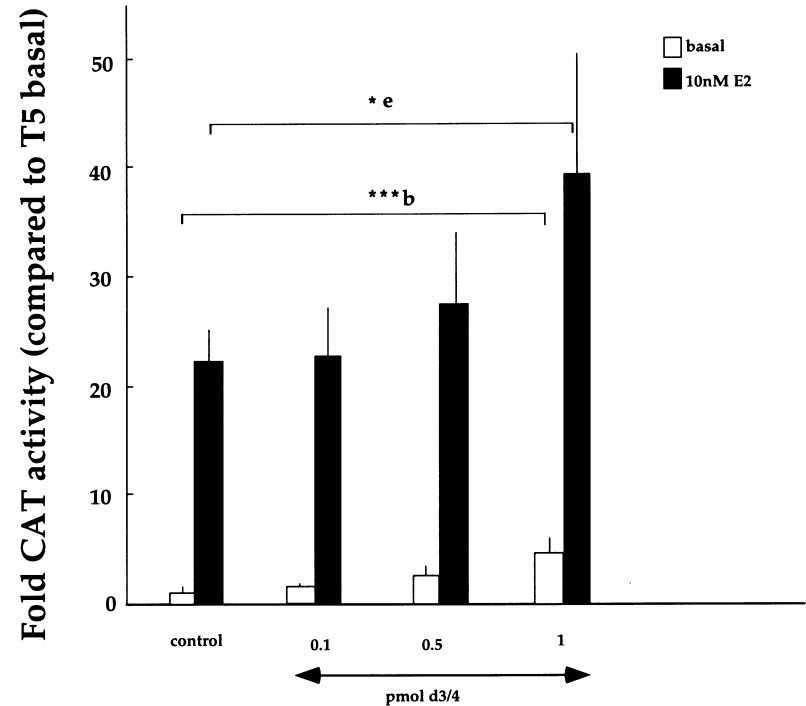

FIgURE 6. Transient transfection of $\mathrm{d} 3 / 4$ expression vector into T5 cells. Cells were grown in PRF-DMEM as described in Materials and Methods and transfected with $5 \mu \mathrm{g}$ ERE-tk-CAT expression vector, $5 \mu \mathrm{g}$ pCH110 along with the appropriate amount of $\mathrm{d} 3 / 4$ expression vector. Cells were treated with vehicle or $10 \mathrm{nM}$ E2 for $24 \mathrm{~h}$, harvested and CAT assays performed. Results represent mean \pm s.E.M., $n=3-5$, *** $\mathrm{b}=P<0 \cdot 0001$, ANOVA, compared with control basal ERE-tk-CAT activity, ${ }^{*} \mathrm{e}=P<0 \cdot 05$, ANOVA, compared with control E2-treated ERE-tk-CAT activity.

does not bind appreciably to ligand in vitro nor has transcriptional activity of its own at this concentration.

\section{DISCUSSION}

Numerous studies have identified variant ER- $\alpha$ mRNAs in both normal and neoplastic breast tissue and cell lines (Garcia et al. 1988, Murphy \& Dotzlaw 1989b, Fuqua et al. 1992, McGuire et al.

FIGURE 5. Activity of $\mathrm{d} 3 / 4$ in ER- $\alpha$-negative cells. (A) MDA-MB-231 cells were transfected with $5 \mu \mathrm{g}$ ERE-tk-CAT, $1 \mu \mathrm{g}$ pCH110, 0.5 pmol HEGO $\pm 0 \cdot 5-$ $2 \mathrm{pmol} \mathrm{d} 3 / 4 \pm$ vector DNA to give a total of $17 \mu \mathrm{g}$ DNA/dish. Cells were treated with $10 \mathrm{nM} \mathrm{E} 2$ for $24 \mathrm{~h}$ or vehicle alone as control. Results are expressed as fold CAT activity compared with basal HEGO activity arbitrarily set as 1 . Columns represent mean \pm s.E.M., $n=6-7$. $* * * \mathrm{e}=P<0 \cdot 0001$ by ANOVA compared with E2-treated HEGO alone. (B) MCF10A1 cells were similarly transfected. Columns represent mean \pm s.E.M., $n=4$. ${ }^{*} \mathrm{e}=P<0 \cdot 05$, ANOVA, compared with E2-treated HEGO alone. 
1992, Leygue et al. 1996a,c). While still a controversial topic, evidence is emerging to support the existence of ER- $\alpha$ variant proteins, which could correspond to some ER- $\alpha$ variant mRNAs, in some cell lines and tissues in vivo (Raam et al. 1988, Marigliante et al. 1991, Moncharmont et al. 1991, Scott et al. 1991, Fuqua et al. 1992, Castles et al. 1993, Montgomery et al. 1993, Pink et al. 1995).

However, the pathophysiological significance of ER- $\alpha$ variant expression is unclear. Altered expression of some ER- $\alpha$ variant mRNAs was found associated with both breast tumorigenesis and breast cancer progression (Fuqua et al. 1992, Daffada et al. 1995, Murphy et al. 1995, Leygue et al. 1996b,c). Several studies, using transient transfection analyses, have shown that individual ER- $\alpha$ variant proteins can have both positive and negative effects on wild-type ER- $\alpha$ activity (Fuqua et al. 1991, 1992, Wang \& Miksicek 1991, Castles et al. 1993, Pink et al. 1995, 1996, Rea \& Parker 1996, Desai et al. 1997). Conflicting results for some ER- $\alpha$ variants have been obtained (Wang \& Miksicek 1991, Fuqua et al. 1993), which may be due to cell- and promoter-specific events previously identified for various structure/function domains of the wild-type ER- $\alpha$ (Tora et al. 1989b, Tzukerman et al. 1994).

Similarly, overexpression of a single ER- $\alpha$ variant using stable transfection technology has resulted in different results in different laboratories (Fuqua \& Wolf 1995, Rea \& Parker 1996). Moreover, direct correlation of any single ER- $\alpha$ variant with clinical tamoxifen resistance or tamoxifen resistance of breast cancer cells in culture has not been forthcoming. Since most of these comparisons have been performed using individual ER- $\alpha$ variants and do not take into account the entire spectrum of ER- $\alpha$ variants relative to each other, the conclusions remain controversial. Together, the data support the hypothesis that the development of hormone independence and endocrine resistance in human breast cancer is a multifactorial process and indeed there are many examples where the development of estrogenindependent growth and antiestrogen resistance are dissociable events in breast cancer cell line models (Katzenellenbogen et al. 1987, Welshons \& Jordan 1987, Van der Berg et al. 1990, Brunner et al. 1993).

Similar to these and other studies, we have found that the development of estrogen-independent growth in a breast cancer cell line model, through long-term growth in estrogen-depleted medium, was not associated with antiestrogen resistance. Although the estrogen-nonresponsive T5-PRF cells have a reduced sensitivity to the pure antiestrogen $\mathrm{ICI}$, their growth response to OT is identical to that of parental T5 cells (Coutts et al. 1996).
However, when we investigated the relative pattern of expression of ER- $\alpha$-deleted variant mRNA in T5-PRF compared with parental T5 cells, there was a significant difference in the relative expression of a previously described exon 3/4deleted ER- $\alpha$ variant mRNA (reviewed in Murphy et al. 1997). Although the question of whether this ER- $\alpha$ variant is a cause of estrogen independence or merely an effect of the selection process for estrogen independence requires further study, our data using transient transfection analyses tend to support a possible functional role for the putative 3/4-deleted ER- $\alpha$ protein encoded by the variant mRNA in the phenotype observed in T5-PRF human breast cancer cells.

In this study we have shown that T5-PRF cells have significantly increased ligand-independent (basal) ER- $\alpha$ activity (reflected in both ERE-tkCAT activity and endogenous PR levels). The recombinant $\mathrm{d} 3 / 4$ variant $\mathrm{ER}-\alpha$ was able to confer significantly increased ligand-independent (basal) and estrogen-responsive transcriptional activity when expressed in parental T5 cells and showed a trend towards increased basal transcriptional activity when coexpressed with wild-type ER- $\alpha$ in ER- $\alpha$-negative human breast cell lines.

While the demonstrated effects of $\mathrm{d} 3 / 4$ on HEGO transcriptional activity in ER- $\alpha$-negative cell lines suggest a putative functional role for this variant ER- $\alpha$, this effect required equal or higher levels of d3/4 than HEGO. Although our data provide 'proof of principle' that the $\mathrm{d} 3 / 4$ variant can modulate the transcriptional activity of the wild-type ER- $\alpha$ the relevance of the expression levels of each protein achieved in the reconstituted transient expression system to the endogenous levels of ER- $\alpha$ and $\mathrm{d} 3 / 4$ variant expression in $\mathrm{T} 5-\mathrm{PRF}$ is unclear. Furthermore, differences in the background of transcriptional coactivators and corepressors between naturally ER- $\alpha$ positive and negative cell lines (for example Tzukerman et al. 1994), as well as the presence of other naturally occurring ER- $\alpha$ variants in naturally ER- $\alpha$ positive cell lines are all likely to impact on the final outcome of ER-mediated transcriptional activity and underlie the differences seen between the transiently manipulated cells and the naturally occurring T5-PRF phenotype. Moreover, expression of ER- $\beta$ and/or its variants may influence estrogen action (Giguere et al. 1998). Both T5 and T5-PRF cells express low levels of ER- $\beta$ mRNA determined by RT-PCR analysis (A S Coutts, H Dotzlaw, E Leygue \& L C Murphy, our unpublished data); however, the functional significance of the levels remains unknown. Nonetheless, we saw a significant effect on ER- $\alpha$ ligandindependent transcription in T5 cells at levels of 
cotransfected $\mathrm{d} 3 / 4$ that likely would not be higher than the endogenous ER- $\alpha$ in these cells, but the extrapolation of these data to the relative expression of wild-type ER- $\alpha$ and $\mathrm{d} 3 / 4$ variant in T5-PRF cells is presently unknown.

It is of significance that we can reproduce an effect of $\mathrm{d} 3 / 4$ variant in the parental $\mathrm{T} 5$ cells, which would likely contain a more representative background of ER- $\alpha$ accessory proteins (i.e. coactivators and/or corepressors) as well as other variant forms of ER- $\alpha$, which would all contribute to the final ER-mediated biological response. As well, our data do not exclude the possibility that other alterations have occurred in T5-PRF cells which, in combination with an altered ER- $\alpha$ variant, may contribute to the estrogen-independent phenotype of T5-PRF cells (Coutts \& Murphy 1998).

It has previously been shown that breast cancer cells can adapt to low levels of estrogen by enhancing their sensitivity to estrogen (Masamura et al. 1995). Estrogen deprivation of MCF-7 human breast cancer cells resulted in estrogen hypersensitivity and maximal growth was achieved with an estrogen concentration 4-5 orders of magnitude lower than wild-type cells. These researchers also found that the concentration of ICI needed to inhibit growth of these cells was $\sim 6$ orders of magnitude lower than wild-type cells, supporting the hypothesis in this model that increased sensitivity to ER ligands had occurred. While supersensitivity to estrogen in T5-PRF cells cannot be entirely ruled out, we have previously shown that in contrast to the data of Masamura et al. (1995), T5-PRF cells are less sensitive to growth inhibition by ICI, suggesting that in this model other mechanisms are likely involved.

Our data do not address the mechanism by which d3/4 enhances ER transcriptional activity, but several possibilities exist. The ER- $\alpha$ contains at least two separate regions that are required for optimal transcriptional activation (Tora et al. 1989b, Tzukerman et al. 1990). The N-terminal region contains promoter and cell-type-specific ligandindependent transcriptional activity (AF1) and the second, AF2, is located in the ligand-binding $\mathrm{C}$-terminus of the receptor. $\mathrm{d} 3 / 4$ containing an intact AF2 or AF1 domain could interfere with, or sequester, an ER- $\alpha$ repressor protein resulting in increased ER- $\alpha$ transcriptional activity in the absence of ligand (Lee et al. 1996). This variant may also retain the ability to interact with other ER- $\alpha$ regulatory proteins such as coactivators or components of the basal transcription machinery.

ER- $\alpha$ also contains two domains involved in dimerization (Kumar \& Chambon 1988, Schwabe et al. 1993). A weak dimerization interface is present in the DBD and a strong interface is located in the C-terminal ligand-binding domain (White et al. 1991). $\mathrm{d} 3 / 4$ containing an intact C-terminal dimerization domain may form heterodimers with wild-type ER- $\alpha$ that have altered transcriptional regulatory properties through differing proteinprotein interactions.

The crystal structure of the ER- $\alpha$ hormonebinding domain has recently been elucidated (Brzozowski et al. 1997). Based on this structure, the $\mathrm{d} 3 / 4$ protein would contain many of the regions essential for transactivation, including the predominant helix 12 (encompassing amino acids 539-547). However, since $\mathrm{d} 3 / 4$ alone has no transcriptional activity (at least on a classical ERE-regulated promoter) the structure must be sufficiently altered to prevent activity, or AF2 can only be activated in a ligand-dependent manner but $\mathrm{d} 3 / 4$ cannot bind ligand. Helix 12 in AF2 is believed to be the main region involved in coactivator recruitment and it may be possible that $\mathrm{d} 3 / 4$, following heterodimerization with ER- $\alpha$, enhances recruitment of coactivators to the basal transcription complex and this enhances ER- $\alpha$ activity.

We have found that the $\mathrm{d} 3 / 4$ caused increased ligand-independent wild-type ER- $\alpha$ activity and also enhances the ligand-induced ER- $\alpha$ transcriptional activity, despite the fact that on its own this variant is not transcriptionally active on a classical ERE promoter, nor does it bind ligand in vitro to any significant degree. Studies have demonstrated that the ability of steroid hormone receptors to modulate transcription does not necessarily require that the receptors bind DNA. PRc, an N-terminally truncated PR isoform lacking the first zinc-finger of the $\mathrm{DBD}$, has no transcriptional activity of its own but has been shown to enhance progestin-induced transcriptional activity (Wei et al. 1996). The DBD of the ER- $\alpha$ does not appear to be necessary for raloxifene activation of the transforming growth factor (TGF)- $\beta$ gene (Yang et al. 1996) and ER- $\alpha$ can activate transcription from AP-1 dependent promoters through a DNA-binding-independent pathway (Webb et al. 1995). Sp1 and ER- $\alpha$ directly interact to enhance estrogen-induced transactivation of the Sp1-dependent Hsp27 gene promoter and the DBD of the ER- $\alpha$ is not required (Porter et al. 1997).

Recent research has demonstrated that the ER- $\alpha$ can be activated in a ligand-independent fashion (Ignar-Trowbridge et al. 1993). Studies have shown that several growth factors such as EGF, TGF- $\alpha$ and insulin-like growth factor-I were able to activate the ER- $\alpha$ in the absence of ligand. The ability to activate the ER- $\alpha$ in the absence of estrogen could confer a growth advantage to breast 
cancer cells and aid in the development of a hormone-independent phenotype. The presence of alternate forms of ER- $\alpha$ capable of interacting with wild-type ER- $\alpha$ to increase ligand-independent activity could also confer a potential growth advantage to breast cancer cells. A recent study has shown that constitutively active, ligandindependent ER- $\alpha$ mutants undergo conformational changes and interactions with coactivators that mimic changes in ER- $\alpha$ that are usually regulated by ligand (Lazennec et al. 1997). Recently, researchers have shown that thyroid hormone receptor- $\beta 2$ (TR- $\beta 2$ ) is a ligand-independent activator of the gene encoding thyrotropin-releasing hormone and have mapped a region in the $\mathrm{N}$-terminus of the receptor responsible for this activity (Langlois et al. 1997). These researchers suggest that the mechanism of ligand-independent activation involves direct interaction of the TR- $\beta 2$ $\mathrm{N}$-terminus with either transcriptional cofactors or the basal transcription machinery itself.

An increased relative expression of variant ER- $\alpha$ proteins containing intact AF domains, could result in increased interactions with the ER- $\alpha$ and/or other proteins involved in ER- $\alpha$ transcriptional activity. This could be a potential mechanism for estrogenindependent growth associated with the presence of one or more variant ER species and could explain the increased ER- $\alpha$ activity we have seen with the $\mathrm{d} 3 / 4$.

\section{ACKNOWLEDGEMENTS}

This work was supported by the US Army Medical Research and Material Command (USAMRMC). L C M is a Medical Research Council of Canada Scientist, $\mathrm{E} \mathrm{L}$ is a recipient of a USAMRMC Postdoctoral Fellowship, and A S C holds a Manitoba Health Research Council Studentship. The authors also wish to acknowledge the generous contribution of the ER antibody, H226, from Dr G Green, University of Chicago, IL, USA.

\section{REFERENCES}

Brunner N, Boulay V, Fojo A, Freter C, Lippman M \& Clarke R 1993 Acquisition of hormone-independent growth in MCF-7 cells is accompanied by increased expression of estrogen regulated genes but without detectable DNA amplifications. Cancer Research 53 283-290.

Brzozowski A, Pike A, Dauter Z, Hubbard R, Bonn T, Engstrom O, Ohman L, Green G, Gustafsson J-A \& Carlquist M 1997 Molecular basis of agonism and antagonism in the oestrogen receptor. Nature 389 753-758.

Castles CG, Fuqua SA, Klotz DM \& Hill SM 1993 Expression of a constitutively active estrogen receptor variant in the estrogen receptor-negative B'T-20 human breast cancer cell line. Cancer Research 53 5934-5939.

Clarke R, Dickson RB \& Brunner N 1990 The process of malignant progression in human breast cancer. Annals of Oncology 1 401-407.

Coutts A \& Murphy L 1998 Elevated mitogen activated protein kinase activity in estrogen non-responsive human breast cancer cells. Cancer Research 58 4071-4074.

Coutts A, Davie J, Dotzlaw H \& Murphy L 1996 Estrogen regulation of nuclear matrix-intermediate filament proteins in human breast cancer cells. Fournal of Cellular Biochemistry 63 174-184.

Daffada AA, Johnston SR, Smith IE, Detre S, King N \& Dowsett M 1995 Exon 5 deletion variant estrogen receptor messenger RNA expression in relation to tamoxifen resistance and progesterone receptor/pS2 status in human breast cancer. Cancer Research 55 288-293.

Desai A, Luqmani Y, Coope R, Dagg B, Gomm J, Pace P, Rees C, Thirunavukkarasu V, Shousha S, Groome N, Coombes R \& Ali S 1997 Presence of exon 5 deleted oestrogen receptor in human breast cancer: functional analysis and clinical significance. British Fournal of Cancer 75 1173-1184.

Dickson R 1991 Growth regulation of normal and malignant breast epithelium. In The Breast: Comprehensive Management of Benign and Malignant Diseases, pp 363-394. Ed. M Lippman. Philadelphia: WB Saunders Co.

Dotzlaw H, Leygue E, Watson P \& Murphy L 1997 Expression of estrogen receptor-beta in human breast tumors. Fournal of Clinical Endocrinology and Metabolism 82 2371-2374.

Fuqua SA \& Wolf DM 1995 Molecular aspects of estrogen receptor variants in breast cancer. Breast Cancer Research and Treatment 35 233-241.

Fuqua SA, Fitzgerald SD, Chamness GC, Tandon AK, McDonnell DP, Nawaz Z, O'Malley BW \& McGuire WL 1991 Variant human breast tumor estrogen receptor with constitutive transcriptional activity. Cancer Research $\mathbf{5 1}$ 105-109.

Fuqua SA, Fitzgerald SD, Allred DC, Elledge RM, Nawaz Z, McDonnell DP, O’Malley BW, Greene GL \& McGuire WL 1992 Inhibition of estrogen receptor action by a naturally occurring variant in human breast tumors. Cancer Research $52483-486$.

Fuqua SA, Allred DC, Elledge RM, Krieg SL, Benedix MG, Nawaz Z, O'Malley BW, Greene GL \& McGuire WL 1993 The ER-positive/PgR-negative breast cancer phenotype is not associated with mutations within the DNA binding domain. Breast Cancer Research and Treatment 26 191-202.

Garcia T, Lehrer S, Bloomer WD \& Schachter B 1988 A variant estrogen receptor messenger ribonucleic acid is associated with reduced levels of estrogen binding in human mammary tumors. Molecular Endocrinology 2 785-791.

Giguere V, Tremblay A \& Tremblay G 1998 Estrogen receptor $\beta$ : re-evaluation of estrogen and antiestrogen signalling. Steroids 63 335-339.

Graham F \& Van der Eb A 1973 A new technique for the assay of infectivity of human adenovirus 5 DNA. Virology $\mathbf{5 2}$ 456-457.

Green S, Walter P, Kumar V, Krust A, Bornert J, Argos P \& Chambon P 1986 Human estrogen receptor cDNA: sequence, expression, and homology to v-erb-A. Nature 320 134-139.

Horwitz KB 1993 Mechanisms of hormone resistance in breast cancer. Breast Cancer Research and Treatment 26 119-130. 
Horwitz KB \& McGuire WL 1978 Estrogen control of progesterone receptor in human breast cancer. Correlation with nuclear processing of estrogen receptor. Fournal of Biological Chemistry 253 2223-2228.

Ignar-Trowbridge D, Teng C, Ross K, Parker M, Korach K \& McLachlan J 1993 Peptide growth factors elicit estrogen receptor dependent transcriptional activation of an estrogen responsive element. Molecular Endocrinology 7 992-998.

Katzenellenbogen B, Kendra K, Norman M \& Berthois Y 1987 Proliferation, hormonal responsiveness, and estrogen receptor content of MCF 7 human breast cancer cells grown in the short term and long term absence of estrogens. Cancer Research 47 4355-4360.

Kingston R 1989 Harvest and assay for chloramphenicol acetyltransferase. Current Protocols in Molecular Biology 1 963-966.

Kumar V \& Chambon P 1988 The estrogen receptor binds tightly to its responsive element as a ligand-induced homodimer. Cell 55 145-156.

Laemmli U 1970 Cleavage of structural proteins during the assembly of the head of bacteriophage T4. Nature 227 680-685.

Langlois M, Zanger K, Monden T, Safer J, Hollenberg A \& Wondisford F 1997 A unique role of the beta 2 thyroid hormone receptor isoform in negative regulation by thyroid hormone. Mapping a novel amino terminal domain important for ligand independent activation. Fournal of Biological Chemistry 272 24927-24933.

Lazennec G, Petz TE, Nardulli A \& Katzenellenbogen B 1997 Mechanistic aspects of estrogen receptor activation probed with constitutively active estrogen receptors: correlations with DNA and coregulator interactions and receptor conformational changes. Molecular Endocrinology 11 $1375-1386$

Lee H, Aumais J \& White J 1996 Hormone dependent transactivation by estrogen receptor chimeras that do not interact with hsp90. Evidence for transcriptional repressors. Fournal of Biological Chemistry 271 25727-25730.

Leonessa F, Boulay V, Wright A, Thompson EW, Brunner N \& Clarke R 1992 The biology of breast tumor progression. Acquisition of hormone independence and resistance to cytotoxic drugs. Acta Oncologica 31 115-123.

Leygue E, Huang A, Murphy L \& Watson P 1996 a Prevalence of estrogen receptor variant messenger RNAs in human breast cancer. Cancer Research 56 4324-4327.

Leygue E, Murphy L, Kuttenn F \& Watson P $1996 b$ Triple primer polymerase chain reaction. A new way to quantify truncated mRNA expression. American Fournal of Pathology 148 1097-1103.

Leygue ER, Watson PH \& Murphy LC 1996c Estrogen receptor variants in normal human mammary tissue. Fournal of the National Cancer Institute 88 284-290.

McGuire WL, Chamness GC \& Fuqua SA 1992 Abnormal estrogen receptor in clinical breast cancer. Fournal of Steroid Biochemistry and Molecular Biology 43 243-247.

Marigliante S, Baker V, Puddefoot J, Barker S \& Vinson G $19914 \mathrm{~S}$ oestrogen receptor isoforms and their distribution in breast cancer samples. Fournal of Molecular Endocrinology 7 205-211.

Masamura S, Santner S, Heitjan D \& Santen R 1995 Estrogen deprivation causes estradiol hypersensitivity in human breast cancer cells. Fournal of Clinical Endocrinology and Metabolism $802918-2925$.

Merkel D \& Osborne C 1989 Prognostic factors in breast cancer. Hematology/Oncology Clinics of North America 3 641-652.

Moncharmont B, Ramp G, De Goeij CC \& Sluyser M 1991 Comparison of estrogen receptors in hormone-dependent and hormone-independent Grunder strain mouse mammary tumors. Cancer Research 51 3843-3848.

Montgomery P, Scott G, Luce M, Kaufmann M \& Benz C 1993 Human breast tumors containing non DNA binding immunoreactive $(67 \mathrm{kDa})$ estrogen receptor. Breast Cancer Research and Treatment 26 181-189.

Murphy LC \& Dotzlaw H $1989 a$ Endogenous growth factor expression in T-47D, human breast cancer cells, associated with reduced sensitivity to antiproliferative effects of progestins and antiestrogens. Cancer Research 49 599-604.

Murphy LC \& Dotzlaw H $1989 b$ Variant estrogen receptor mRNA species detected in human breast cancer biopsy samples. Molecular Endocrinology 3 687-693.

Murphy LC, Hilsenbeck SG, Dotzlaw H \& Fuqua SAW 1995 Relationship of clone 4 estrogen receptor variant messenger RNA expression to some known prognostic variables in human breast cancer. Clinical Cancer Research 1 155-159.

Murphy L, Dotzlaw H, Leygue E, Douglas D, Coutts A \& Watson P 1997 Estrogen receptor variants and mutations: a review. Fournal of Steroid Biochemistry and Molecular Biology $62363-372$.

Nandi S, Guzman R \& Yang J 1995 Hormones and mammary carcinogenesis in mice, rats and humans: a unifying hypothesis. Proceedings of the National Academy of Sciences of the USA 92 3650-3657.

Pink JJ, Jiang SY, Fritsch M \& Jordan VC 1995 An estrogenindependent MCF-7 breast cancer cell line which contains a novel 80-kilodalton estrogen receptor-related protein. Cancer Research 55 2583-2590.

Pink JJ, Wu SQ, Wolf DM, Bilimoria MM \& Jordan VC 1996 A novel $80 \mathrm{kDa}$ human estrogen receptor containing a duplication of exons 6 and 7. Nucleic Acids Research 24 962-969.

Porter W, Saville B, Hoivik D \& Safe S 1997 Functional synergy between the transcription factor $\mathrm{Sp} 1$ and the estrogen receptor. Molecular Endocrinology 11 1569-1580.

Raam S, Robert N, Pappas C \& Tamura H 1988 Defective estrogen receptors in human mammary cancers: their significance in defining hormone dependence. Fournal of the National Cancer Institute 80 756-761.

Rea D \& Parker MG 1996 Effects of an exon 5 variant of the estrogen receptor in MCF-7 breast cancer cells. Cancer Research 56 1556-1563.

Rosenthal N 1987 Identification of regulation elements of cloned genes with functional assays. Methods in Enzymology 152 704-720.

Schwabe J, Chapman L, Finch J \& Rhodes D 1993 The crystal structure of the estrogen receptor DNA binding domain bound to DNA: how receptors discriminate between their response elements. Cell 75 567-578.

Scott G, Kushner P, Vigne J-L \& Benz C 1991 Truncated forms of DNA-binding estrogen receptors in human breast cancer. Fournal of Clinical Investigation 88 700-706.

Seiler-Tuyns A, Walker P, Martinez E, Merillat A, Givel F $\&$ Wahli W 1986 Identification of estrogen-responsive DNA sequences by transient expression experiments in a human breast cancer cell line. Nucleic Acids Research 14 $8755-8770$.

Tora L, Mullick A, Metzger D, Ponglikitmongkol M, Park I \& Chambon P $1989 a$ The cloned human oestrogen receptor contains a mutation which alters its hormone binding properties. EMBO fournal 8 1981-1986.

Tora L, White J, Brou C, Tasset D, Webster N, Scheer E \& Chambon P $1989 b$ The human estrogen receptor has two independent nonacidic transcriptional activation functions. Cell 59 477-487. 
Tzukerman M, Zhang XK, Hermann T, Wills KN, Graupner G \& Pfahl M 1990 The human estrogen receptor has transcriptional activator and repressor functions in the absence of ligand. New Biology 2 613-620.

Tzukerman M, Esty A, Santiso-Mere D, Danielian P, Parker M, Stein R, Pike J \& McDonnell D 1994 Human estrogen receptor transactivational capacity is determined by both cellular and promoter context and mediated by two functionally distinct intramolecular regions. Molecular Endocrinology 8 21-30.

Van der Berg H, Martin J \& Lynch M 1990 High progesterone receptor concentration in a variant of the ZR-75-1 human breast cancer cell line adapted to growth in oestrogen free conditions. British Fournal of Cancer 61 504-507.

Wang Y \& Miksicek RJ 1991 Identification of a dominant negative form of the human estrogen receptor. Molecular Endocrinology 5 1707-1715.

Watts C, Handel M, King R \& Sutherland R 1992 Oestrogen receptor gene structure and function in breast cancer. Fournal of Steroid Biochemistry and Molecular Biology 41 529-536.
Webb P, Lopez GN, Uht RM \& Kushner PJ 1995 Tamoxifen activation of the estrogen receptor/AP-1 pathway: potential origin for the cell-specific estrogen-like effects of antiestrogens. Molecular Endocrinology 9 443-456.

Wei L, Hawkins P, Baker C, Norris B, Sheridan P \& Quinn P 1996 An amino terminal truncated progesterone receptor isoform, PRc, enhances progestin induced transcriptional activity. Molecular Endocrinology 10 1379-1387.

Welshons W \& Jordan V 1987 Adaptation of estrogen dependent MCF 7 cells to low estrogen (phenol red free) culture. European Fournal of Cancer and Clinical Oncology 23 1935-1939.

White R, Fawell S \& Parker M 1991 Analysis of oestrogen receptor dimerisation using chimeric proteins. Fournal of Steroid Biochemistry and Molecular Biology 40 333-341.

Yang NN, Venugopalan M, Hardikar S \& Glasbrook A 1996 Identification of an estrogen response element activated by metabolites of 17-beta estradiol and raloxifene. Science $\mathbf{2 7 3}$ 1222-1225.

REVISED MANUSCRIPT RECEIVED 16 July 1999 